СТАТЬИ

УДК 551.345

ТЕМПЕРАТУРНЫЙ РЕЖИМ МНОГОЛЕТНЕМЕРЗЛЫХ ПОРОД НА ПОСТПИРОГЕННЫХ УЧАСТКАХ СЕВЕРА КОЛЫМСКОЙ НИЗМЕННОСТИ

\author{
${ }^{1}$ Андреева В.В., ${ }^{1}$ Максимов Г.Т., ${ }^{1}$ Спектор В.В., ${ }^{2}$ Холодов А.Л., ${ }^{3}$ Давыдов С.П. \\ ${ }^{1}$ Институт мерзлотоведения им. П.И. Мельникова СО РАН, Якутск, е-mail: Varvara-andreev@mail.ru; \\ ${ }^{2}$ Институт физико-химических и биологических проблем почвоведения РАН, Пушчно; \\ ${ }^{3}$ Тихоокеанский институт географии ДВО РАН, Северо-Восточная научная станция, Черский
}

\begin{abstract}
Техногенное влияние на бореальные леса (вырубка, удаление напочвенного покрова, строительство линейных сооружений, расширение населенных пунктов) приводит к значительному изменению геокриологических условий. При этом наиболее разрушительным и непредсказуемым фактором служат природные пожары, причиной которых чаще всего является человеческая деятельность. Ежегодно пожары уничтожают лесной покров на значительных территориях криолитозоны. В статье представлены результаты комплексных исследований высокольдистых отложений на постпирогенных участках в Нижнеколымском районе Республики Саха (Якутия) вблизи пос. Черский. В ходе ландшафтной типизации и геоботанической съемки выделены ключевые участки притундровых редколесий с разновозрастными лесными пожарами и стадиями сукцессий растительности. На каждой площадке пробурены скважины, проведен комплексный анализ кернового материала и организованы мониторинговые площадки по изучению температурного режима многолетнемерзлых пород. По результатам работ выяснены особенности криолитологического строения и оценен температурный режим мерзлых пород в слое годовых теплооборотов на постпирогенных участках. Лесные пожары на рассматриваемых участках, подстилаемых ледовым комплексом, не инициировали процесс термокарста. В ходе работ на ключевых участках, несмотря на наличие современных морозобойных трещин на поверхности, термопросадок по полигональной сетке ледового комплекса обнаружено не было. Стабилизация температур грунтов на постпирогенных участках происходит интенсивно с каждой стадией сукцессионного развития растительности. На основе выполненных работ установлено, что температура грунтов на рассматриваемой территории севера Колымской низменности изменяется от $-2,0^{\circ} \mathrm{C}$ на межаласье до $-6,0^{\circ} \mathrm{C}$ на высокой пойме.
\end{abstract}

Ключевые слова: криогенное строение, слой годовых теплооборотов, слой сезонного оттаивания, температурный режим, лесные пожары, север Колымской низменности

\title{
TEMPERATURE REGIME OF THE PERMAFROST ON POSTPYROGENIC SITES IN THE NORTH OF KOLYMA LOWLAND
}

${ }^{1}$ Andreeva V.V., ${ }^{1}$ Maksimov G.T., ${ }^{1}$ Spektor V.V., ${ }^{2}$ Kholodov A.L., ${ }^{3}$ Davydov S.P.

${ }^{1}$ Melnikov Permafrost Institute SB RAS, Yakutsk, e-mail:Varvara-andreev@mail.ru;

${ }_{2}^{2}$ Institute of Physicochemical and Biological Problems at Soil Science, RAS, Moscow region, Pushchino;

${ }^{3}$ North-East Science Station Pacific Geographical Institute of FEB RAS, Cherskiy

Technogenic impact on boreal forests, such as deforestation, removal of ground cover, construction of linear structures, expansion of settlements, leads to a significant change in geocryological conditions. Moreover, the most destructive and unpredictable factor is forest fires, which are most often caused by human activity. Every year, fires destroy forest cover in large areas of the permafrost. The article presents the results of comprehensive studies of ice-rich sediments in post-pyrogenic areas in the Nizhnekolymsk region of the Republic of Sakha (Yakutia) near Chersky. In the course of landscape typification and geobotanical surveys, key areas of pre-tundra woodlands with forest fires of different ages and stages of vegetation succession were identified. At each site we were drilled boreholes, a comprehensive analysis of core material was carried out and monitoring sites were organized to observe the temperature regime of permafrost. Based on the results of the work, the features of the cryolithological structure were clarified and the temperature regime of frozen rocks in the layer of annual heat turnover in post-pyrogenic areas was estimated. Forest fires in the areas under consideration, underlain by the ice complex, did not initiate the thermokarst process. During the work in key sites, despite the presence of modern frost cracks on the surface, no thermal subsidence was found along the polygonal grid of the ice complex. Stabilization of soil temperatures in postpyrogenic sites occurs intensively with each stage of the successional development of vegetation. Based on the work performed, it was established that the temperature of the soil in the considered territory of the north of the Kolyma lowland varies from $-2.0^{\circ} \mathrm{C}$ at the inter-alas, to $-6.0^{\circ} \mathrm{C}$ at the high floodplain.

Keywords: cryogenic structure, layer of annual heat turnover, active layer, temperature regime, forest fires, North of Kolyma lowland

Лесной пожар как стихийное бедствие наносит огромный урон природной среде. Происходят пожары часто и повсеместно, кратковременно и долгосрочно, на небольшой площади или охватывая все больше территорий, достигая сотен гектаров. Возникают они как по природным причинам (из-за ударов молний, самовозгорания торфяной крошки и т.д.), так и из-за деятельности человека (сельхозпалов, охоты, лесозаготовок, техногенных аварий, халатного обращения с огнем и т.д.). Ежегодно пожары уничтожают лесной покров назначительных территориях Якутии. Так, в период пожаро- 
опасных сезонов 2019 г. и 2020 г. в регионе было зарегистрировано 1865 и 2061 лесных пожаров на общей площади 4 млн га и 6,3 млн га соответственно [1].

Исследования влияния лесных пожаров в криолитозоне проводятся достаточно широко, причем большинство работ посвящено изучению реакции на пожары лесного биома и почв [2-4]. Первоначально повышенная огневая активность пожара на территории криолитозоны изменяет условия теплообмена на поверхности, прежде всего уменьшая поверхностное альбедо. Это приводит к заметному изменению теплового, водного и мерзлотного режимов грунтов [5]. Ряд работ по изучению влияния пожаров на температурные режимы многолетнемерзлых толщ и параметры мерзлотных ландшафтов выполнялся сотрудниками Института мерзлотоведения СО РАН $[6,7]$. Однако в приведенных работах рассматривается влияние пожаров на первые метры почвогрунтов от поверхности, вследствие этого сложно оценить воздействие пожаров на изменение термического состояния криолитозоны и многолетнюю динамику мерзлотных ландшафтов.

Коллективом автором ведутся мониторинговые работы по изучению теплового состояния многолетнемерзлых пород в Нижнеколымском районе. Целью исследований является оценка влияния лесных пожаров на мерзлотные ландшафты и строение верхних горизонтов многолетнемерзлых пород.

Район исследований и методика работ

Исследуемые постпирогенные участки расположены в низовьях р. Колыма, в окрестностях пос. Черский (Нижнеколымский район РС (Я)), на склоновых, межаласных и пойменных поверхностях с различными стадиями послепожарного развития растительности (рис. 1). Из них 2 участка находятся на межаласье - 13/1 заказник «Плейстоценовый парк» (возраст пожара 120 лет) и 18/3 оз. Тубдиспансерное (возраст пожара 40 лет), 2 площадки - на склоновом типе местности - 20/1 г. Родинка (пожар произошел в июне 2020 г.), 18/2 руч. Комарок (возраст пожара 80 лет) и 2 участка - на пойме 19/2 (пойма Колымы) - пожар 15-летней давности, 3-07 - контрольный участок, с ненарушенными условиями. Фотографии мониторинговых площадок приведены на рис. 3.

Согласно мерзлотно-ландшафтной типизации исследуемая территория входит в состав Северо-Анюйской низкогорной провин- ции, в соответствии с дифференциацией широтно-зональных параметров рассматриваемые участки располагаются на северотаежном и интразональном ландшафтах [7].

По результатам анализа данных космоснимков и рекогносцировочных работ были выбраны ключевые участки со свидетельствами лесного пожара (обугленные фрагменты древесины, заваленные стволы деревьев) и с современным лесным пожаром, произошедшим в июне 2020 г. На выделенных участках осуществлена геоботаническая съемка местности. Проведены буровые работы колонковым способом установкой УКБ 12-25 с последующей организацией мониторинговой площадки. Глубины скважин (скв.) варьируют от 9 до 21 м. По материалу буровых кернов изучено криолитологическое строение отложений. По керновому материалу определены весовая влажность (методом высушивания до постоянной массы [8]); методом взвешивания образцов мерзлых пород в нейтральной жидкости определены объемный вес и общее содержание органического вещества, полученное путем прокаливания сухих образцов при температуре $450^{\circ} \mathrm{C}$. Гранулометрический состав грунта определен ситовым и ареометрическим методами в Институте мерзлотоведения [9]. После бурения скважины обсаживались пластиковыми трубами, в которые в последующем были помещены температурные датчики и автоматические логгерные системы Onset Hobo U-12-008. Датчики размещены на разных глубинах. Для оценки динамики температур грунтов слоя сезонного оттаивания на нескольких площадках установлены 2-канальные логгеры Onset Hobo U-23-003. Измерения температур грунтов в скважинах производятся с интервалом 6 и 12 ч.

\section{Результаты работ}

Одним из основных факторов, обусловливающих изменения температурного режима многолетнемерзлых пород, является растительность (рис. 2). Важным моментом является то, что растительный покров как защитная оболочка часто подвергается разрушению пожарами, приводящими к полному или частичному уничтожению органогенного горизонта. В зависимости от интенсивности пожара и его давности растительные сукцессии на постпирогенных участках могут развиваться по-разному. Характеристика растительных ассоциаций на каждом мониторинговом участке кратко приведена в табл. 1. 


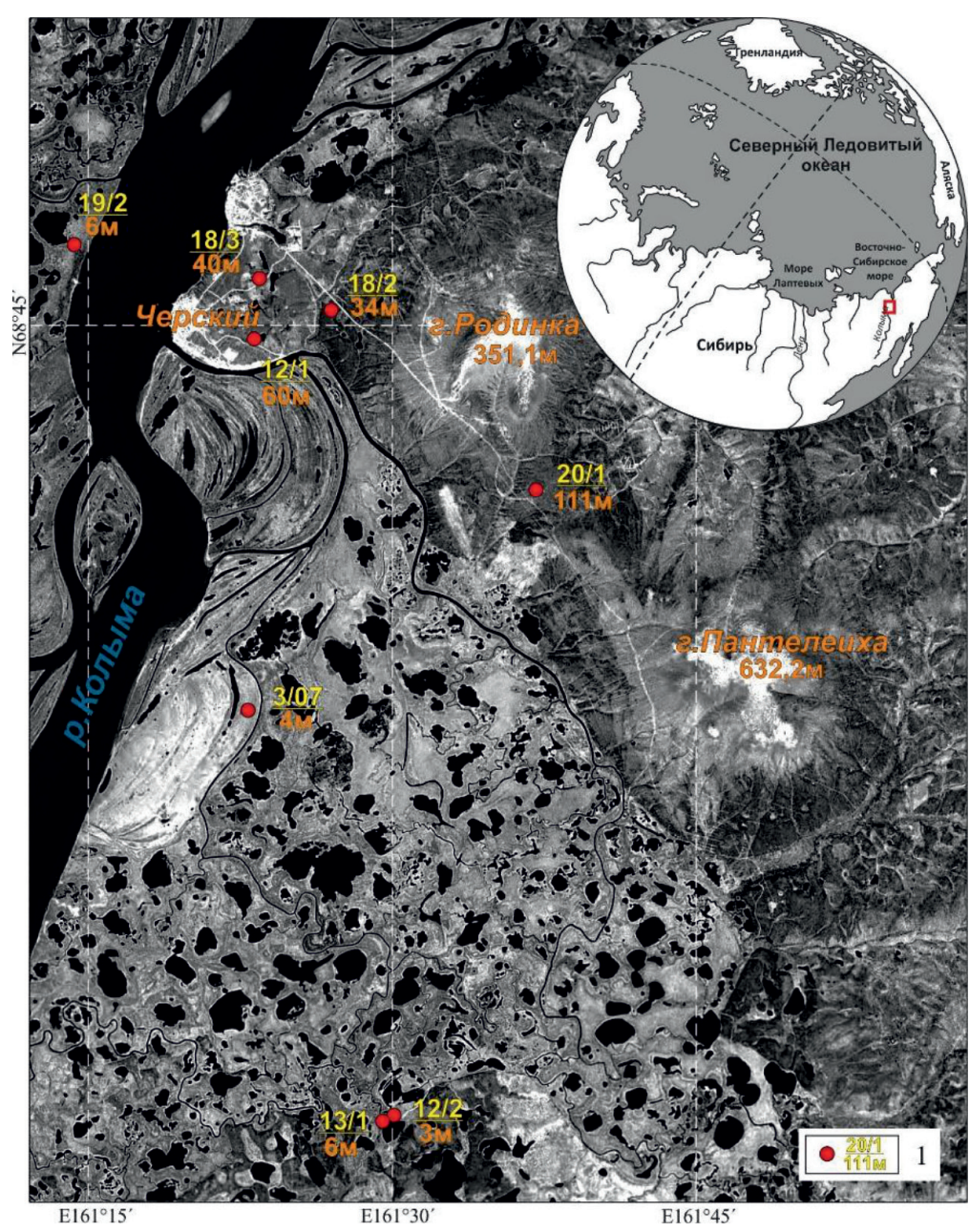

Рис. 1. Схема района работ, фрагмент топографической карты 1:10000; красными точками обозначены мониторинговые площадки;

в числителе - номер скв., в знаменателе - абсолютная высотная отметка

В общих чертах растительность района исследований в верхнем ярусе представлена основном лиственницей Каяндера (Larix cajanderi) высотой до 12 м (в среднем 8 м), толщиной стволов от $0,01 \mathrm{м}$ до $0,4 \mathrm{M}$, сомкнутость крон невысокая $(0,2-0,4)$. Кустарниковый ярус представлен березкой (Betula exilis и B. divaricata), ольхой кустарниковой (Duschekia fruticosa) и несколькими видами ив (Salix glauca, S. pulchra, S. alaxensis, S. Krylovii и др.). Из кустарничков обычны: брусника (Vaccinium vitis-idaea), голубика (Vaccinium uliginosum), багульник стелющийся (Ledum decumbens) и два вида арктоуса: арктоус альпийский и а. красноплодный (Arctous alpina, A. erythrocarpa). Травянистая растительность в основном представлена вейником незамечаемым (Calamagrostis neglecta), арктополевицей широколистной (Arctagrostis latifolia), грушанкой мясо-красной (Pyrola incarnata), валерианой головчатой (Valeriana capitata) и ожикой спутанной (Luzula confusa), несколькими видами осок и иными видами разнотравья. В нижнем ярусе встречается хвощ камышковый (Equisetum scirpoides). Проективное покрытие мохово-лишайникового покрова достигает $90 \%$. Из мхов обычны: аулакомниум болотный и вздутый (Aulacomnium palustre и A.turgidum), птилидиум реснитчатый (Ptilidium ciliare), политрихум сжатый (Polytrichum strictum), гилокомиумом блестящий (Hylocomium splendens) и Bryum sp. Среди лишайников отмечаются: цетрария клобучковая и снежная (Cetraria cuculata и C. nivalis), пельтигера пупырчатая (Peltigera aptosa), дактилина арктическая (Dactylina arctica), кладония звездчатая (Cladonia stellaris) и оленья (C. rangiferina), стереокаулон альпийский (Stereocaulon alpinum), а также несколько видов Cladonia и прочие виды лишайников. 
Криолитологическое описание и результаты лабораторных исследований кернового материала приведены в табл. 1 и на рис. 4.
Криолитологические разрезы и диаграммы гранулометрического состава представлены на рис. 3.

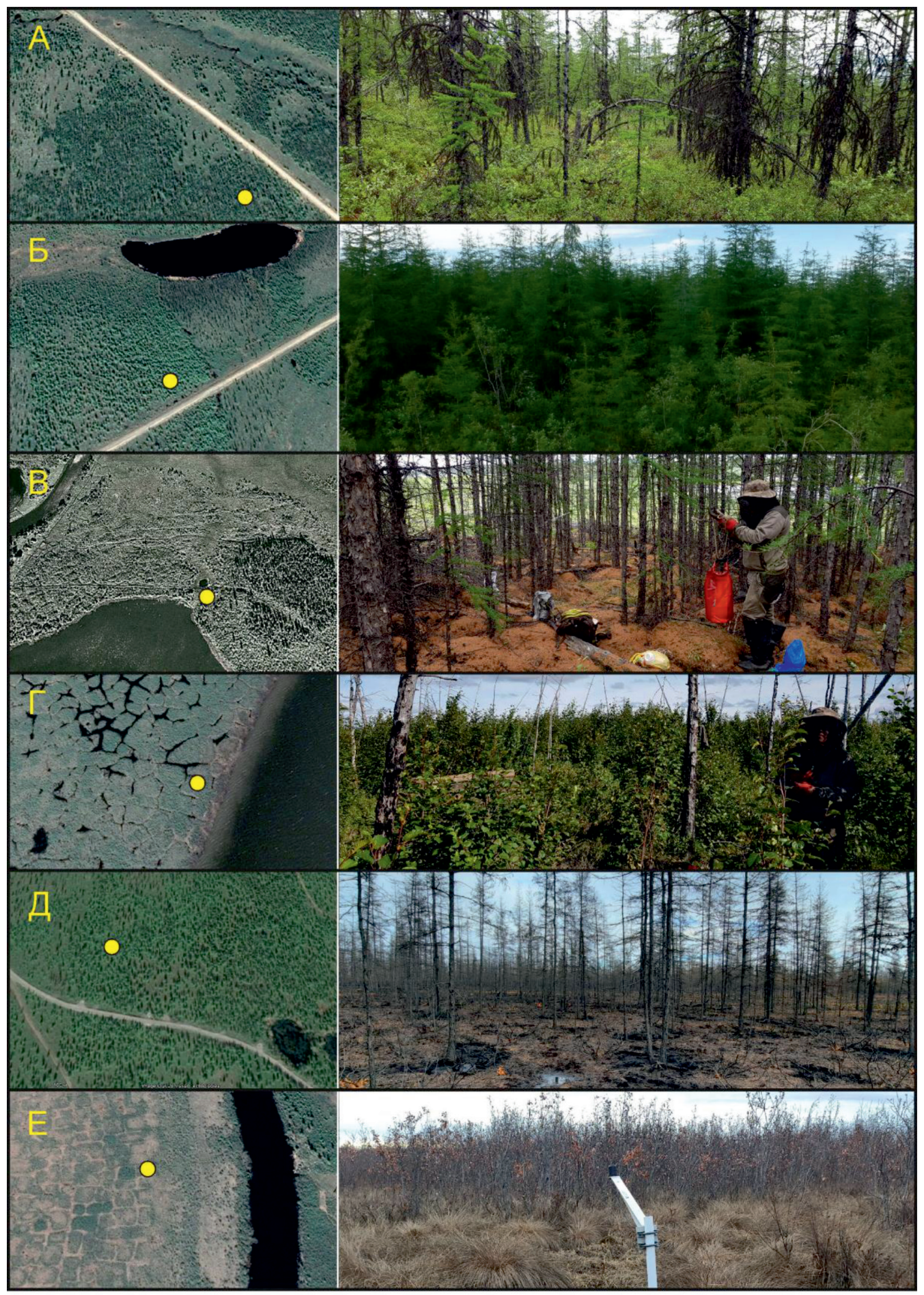

$100 \mathrm{M}$

Рис. 2. Общий вид растительных ассочиаций по площзадам: А - скв. $18 / 2$ ручей Комарок;

Б-скв. 18/3 оз. Тубдиспансерное; В - 13/1 Плейсточеновый парк; $Г-19 / 2$ пойма Кольмы;; Д-20/1 склон г. Родинка; E-3/07 пойма протоки Амболиха; желтым кругом обозначены скважины 


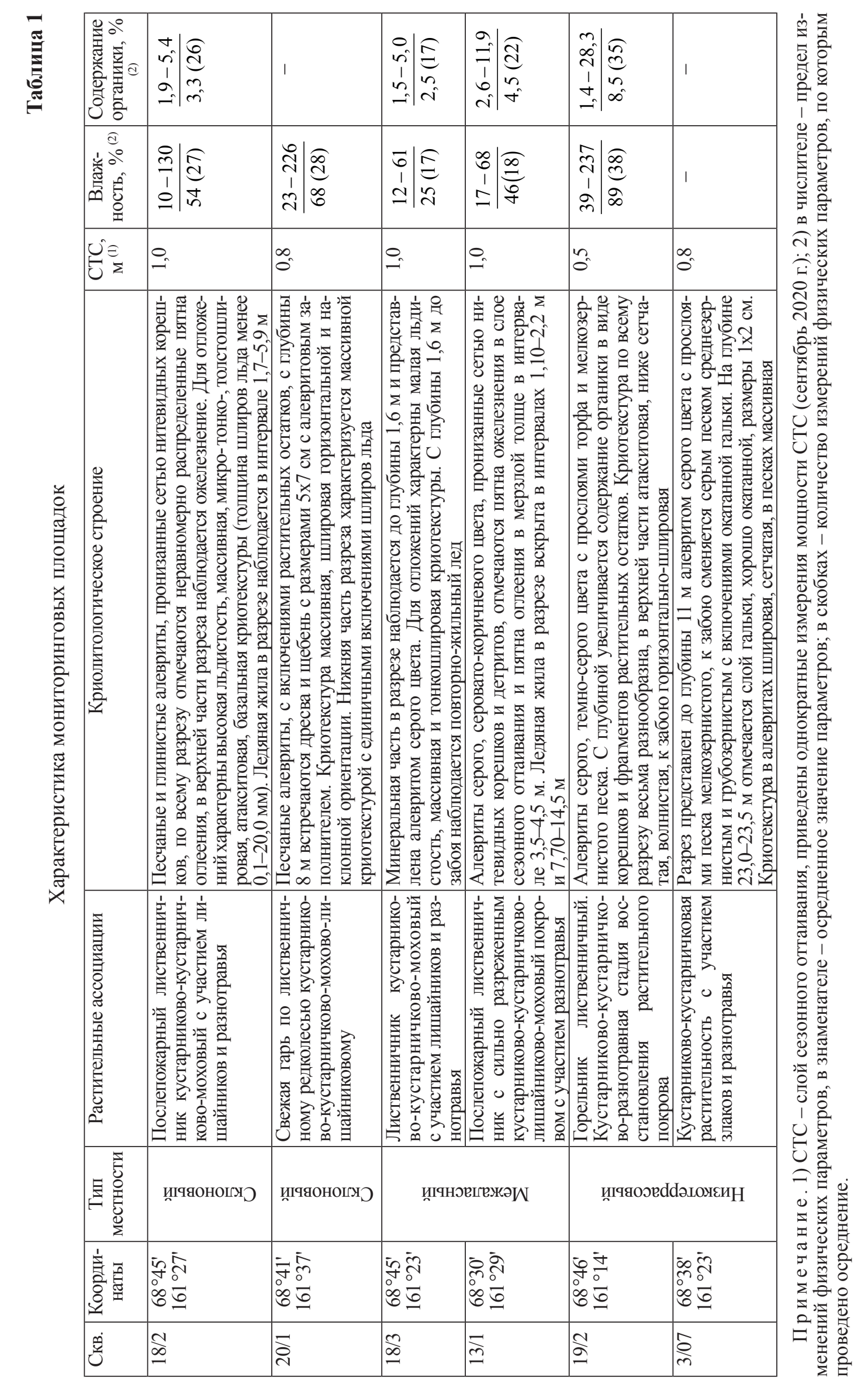

- УСПЕХИ СОВРЕМЕННОГО ЕСТЕСТВОЗНАНИЯ № 8, 2021 

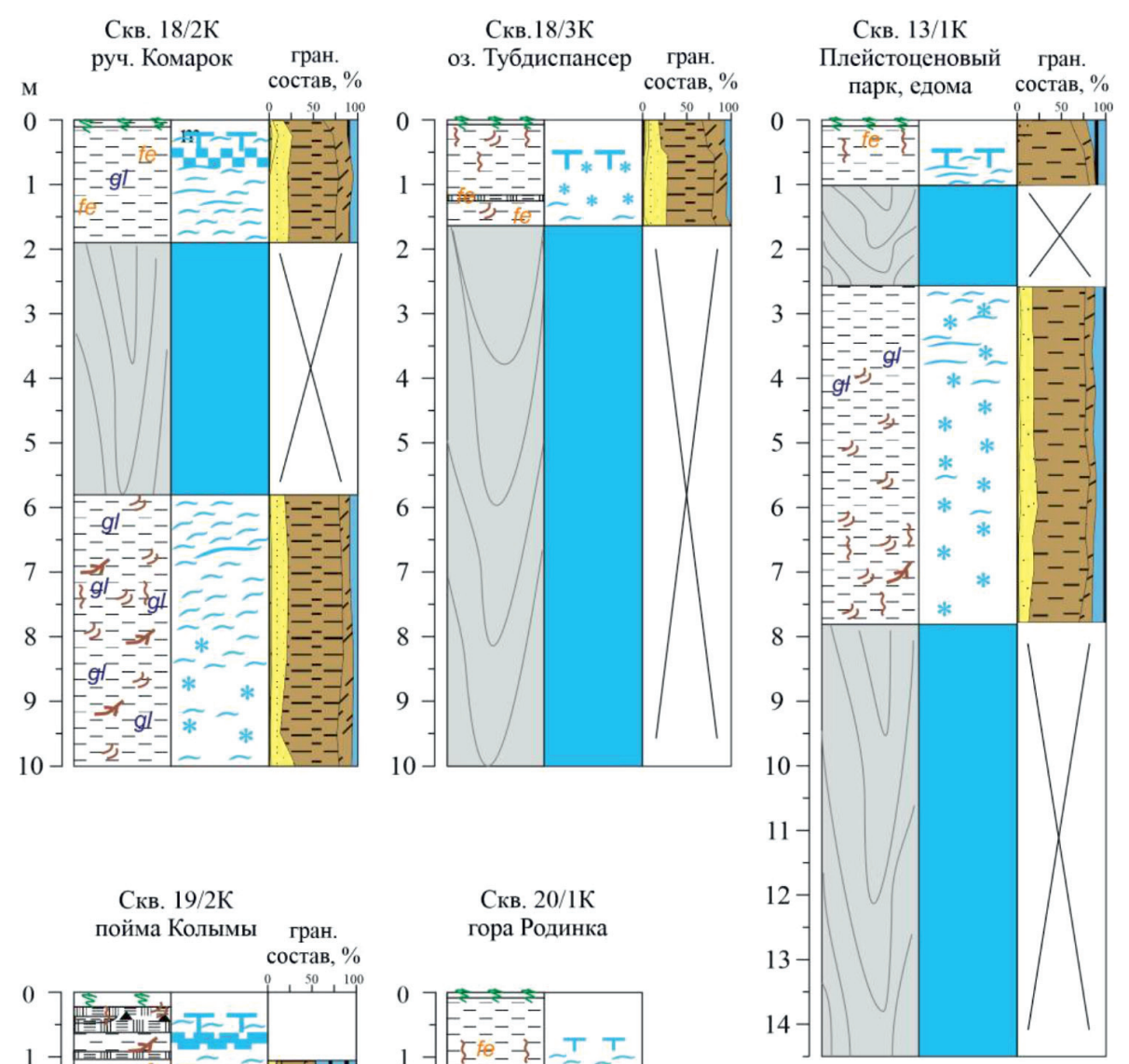

прот. Амболиха
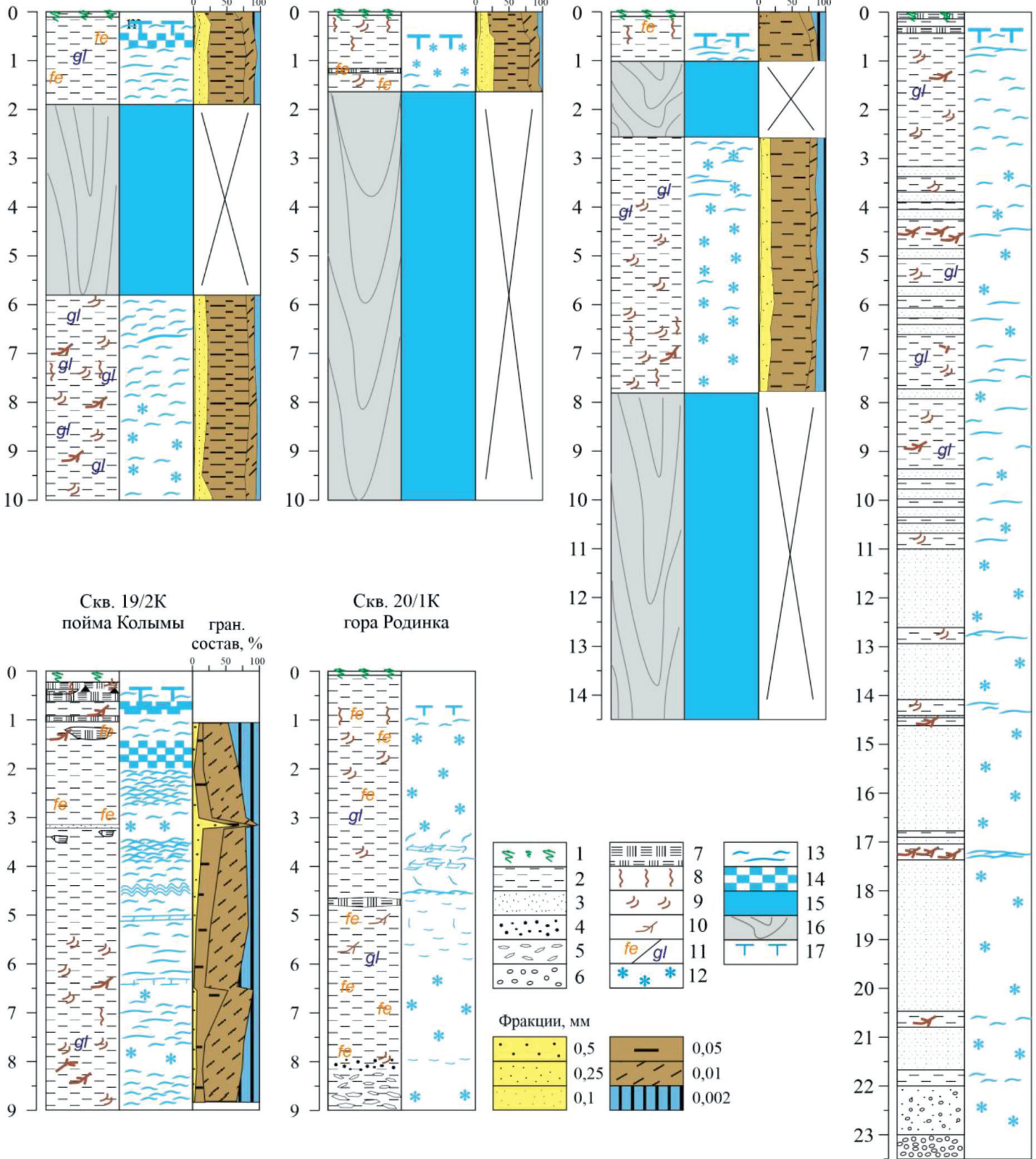

Рис. 3. Криолитологические разрезы и гранулометрический состав отложений на мониторинговых площадках, условные обозначения: 1 - почвенно-растительный слой; 2 - алевритыл; 3 - песок; 4-дресва; 5 -щебень; 6-галька; 7 - торф; 8- нитевидные корешки; 9 - растительные остатки; 10 - древесный детрит; 11 - ожелезнение/оглеение; 12 -массивная криотекстура; 13 - шлировая криотекстура; 14 - атакситовая криотекстура; 15 -лед; 16 - повторно-жильный лед; 17 - граница ММП 

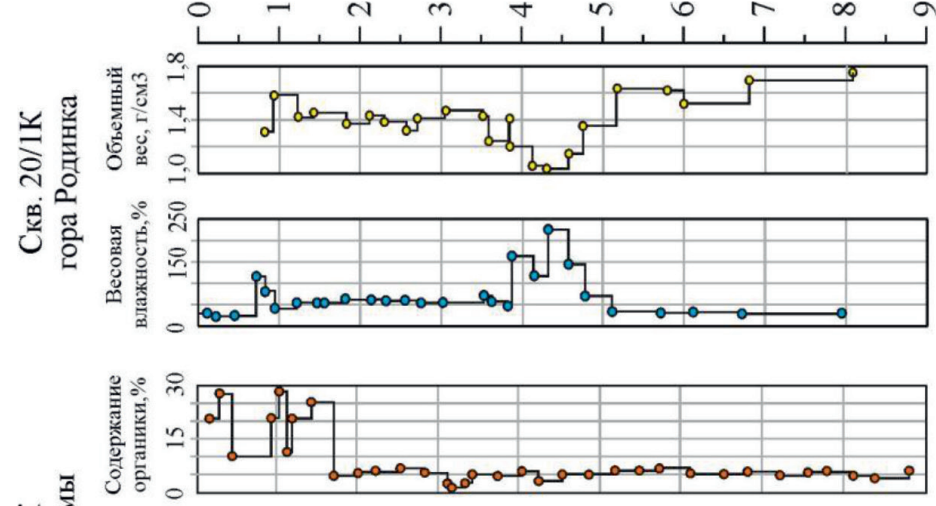

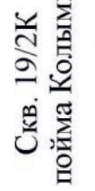

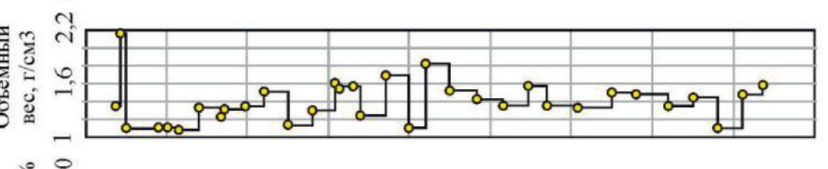

惫

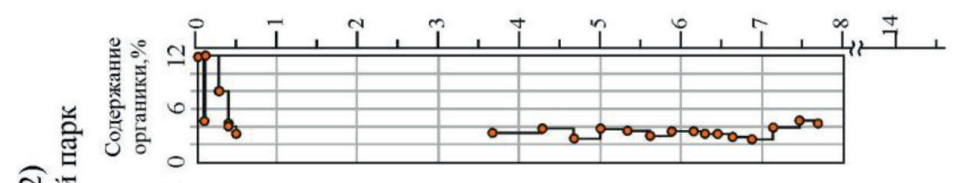

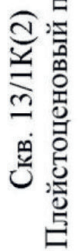

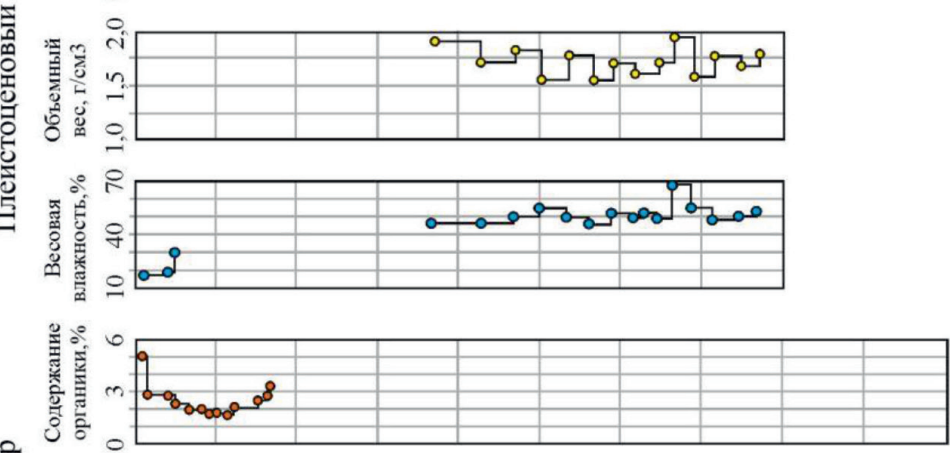

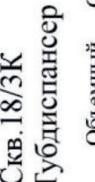

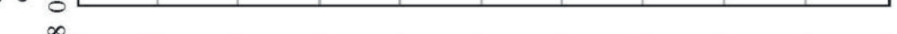

gro

至 80

\%
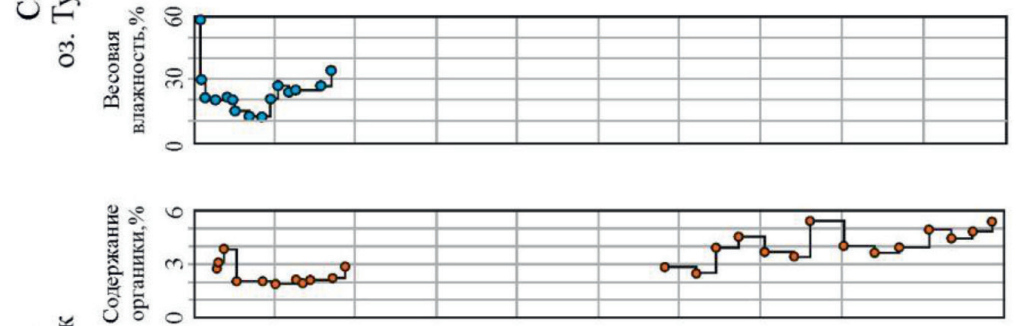

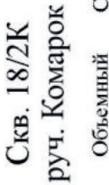
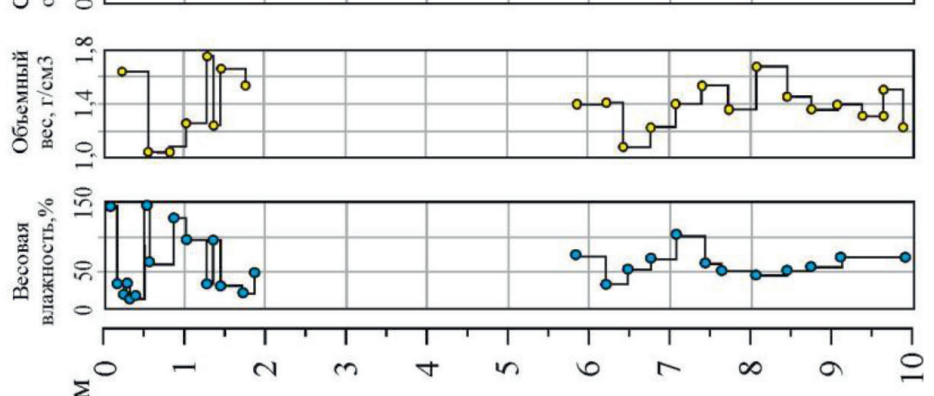
Температура мерзльхх пород. По данным метеостанции Черский, среднегодовая температура воздуха в период с 2013 по 2020 гг. изменялась в пределах от $-7,4^{\circ} \mathrm{C}$ до $-9,9^{\circ} \mathrm{C}$, среднелетняя (июнь - август) - от $10,6^{\circ} \mathrm{C}$ до $12,4^{\circ} \mathrm{C}$, среднезимняя (декабрь - февраль) изменялась в диапазоне от $-27,6^{\circ} \mathrm{C}$ до $-30,6^{\circ} \mathrm{C}$. Годовая амплитуда среднемесячных температур менялась в пределах $43-51^{\circ} \mathrm{C}$. Переход к отрицательным среднесуточным температурам происходит в конце сентября, а к положительным - в середине мая. Количество атмосферных осадков за наблюдаемый период составило от 211 до 406 мм. Из них на долю снежного покрова приходится от 95 до 206 мм. Снежный покров держится в среднем 225 дней, при этом мощность в разные годы варьирует в пределах 50-60 см, а в отдельные многоснежные зимы может достигать 93 см (в 2018 г.). На мониторинговых площадках мощность слоя сезонного оттаивания изменяется в диапазоне от 0,4 до 1,0 м. В 2017 и 2018 гг. отмечаются повышение среднегодовой температуры воздуха $-7,6^{\circ} \mathrm{C}$ и $-7,4^{\circ} \mathrm{C}$ соответственно и увеличение мощности снежного покрова до $93 \mathrm{~cm}$.

Скв. 13/1 выполнена на локальном водоразделе, останце едомной поверхности в заказнике Плейстоценовый парк. Монито- ринг температур на этой площадке ведется с 2013 г., датчики размещены на глубинах 0,5; 5; 10; 14 м. Среднегодовые температуры в период с 2013 по 2020 гг. на глубине 14 м изменялись в диапазоне от $-4,7^{\circ} \mathrm{C}$ до $-5,9^{\circ} \mathrm{C}$, на глубине $10 \mathrm{M}-$ от $-4,2^{\circ} \mathrm{C}$ до $-5,9^{\circ} \mathrm{C}$, на $5 \mathrm{M}-$ от $-3,7^{\circ} \mathrm{C}$ до $-5,7^{\circ} \mathrm{C}$. Как видно из табл. 3 и рис. 5, в 2017-2018 гг. на глубине 5 м существенно сократилась амплитуда колебания температуры, в эти годы отмечается наиболее высокая среднегодовая температура грунтов: $-3,7^{\circ} \mathrm{C}$ и $-4,0^{\circ} \mathrm{C}$ соответственно.

В скв. 3/07, расположенной на пойме протоки Амболиха, в период с 2013 по 2020 гг. на глубине 21 м среднегодовая температура изменялась в диапазоне от $-5,2^{\circ} \mathrm{C}$ до $-5,9^{\circ} \mathrm{C}$, на глубине $14 \mathrm{~m}-$ от $-5,4^{\circ} \mathrm{C}$ до $-6,0^{\circ} \mathrm{C}$. Так же как и на площадке 13/1, в 2017-2018 гг. отмечаются резкое повышение среднегодовых температур грунтов и сокращение амплитуды колебаний на глубине 4 м (рис. 5, табл. 2). Вероятно, столь существенное повышение температур пород связано с многоснежностью зим и повышением среднегодовой температуры воздуха в данные периоды.

Результаты температурных наблюдений мерзлых пород на межаласье, склоне и пойме (скв. $18 / 2,18 / 3$ и 19/2) и их сопоставление с данными метеостанции Черский представлены на рис. 6 .

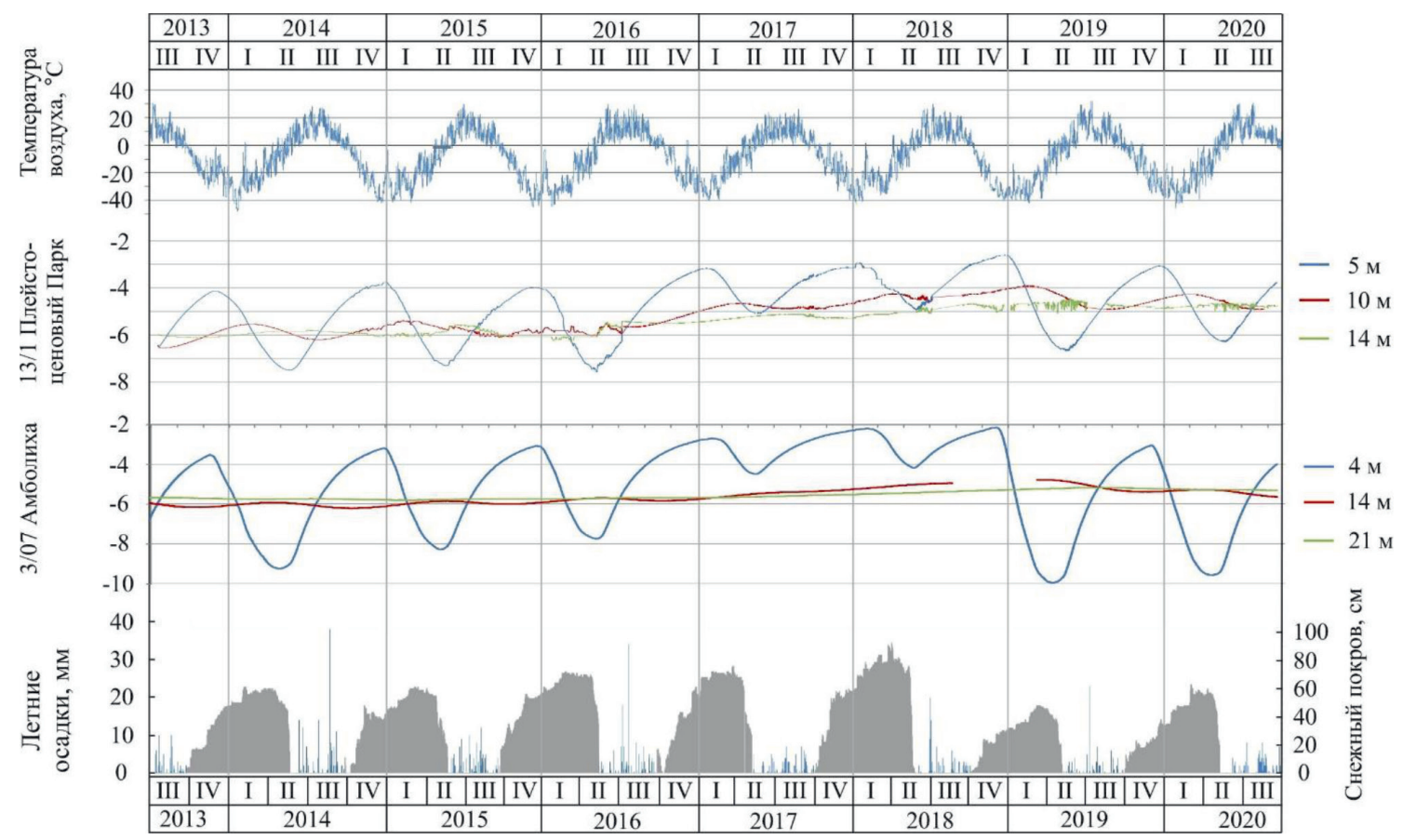

Рис. 5. Сопоставление метеоданных ст. Черский и температур мерзлых пород в скважинах 13/1 и 3/07 за период 2013-2020 г2. 
שָ

\begin{tabular}{|c|c|c|c|c|c|c|c|c|c|c|c|c|c|c|c|c|}
\hline \multirow{5}{*}{\multicolumn{2}{|c|}{ 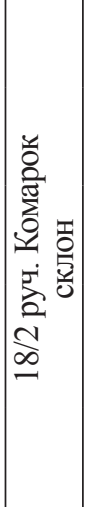 }} & $\stackrel{0}{0}$ & 1 & 1 & 1 & 1 & 1 & 1 & 1 & 1 & 1 & 1 & $\stackrel{m}{+}$ & 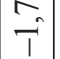 & $\stackrel{+}{+}$ & $\stackrel{+}{\rightarrow}$ \\
\hline & & in & 1 & 1 & 1 & 1 & 1 & 1 & 1 & 1 & 1 & 1 & $\stackrel{F}{F^{*}}$ & $\begin{array}{l}2 \\
+\end{array}$ & $\begin{array}{l}0 \\
+ \\
+\end{array}$ & iे \\
\hline & & $m$ & 1 & 1 & 1 & 1 & 1 & 1 & 1 & 1 & 1 & 1 & $\overrightarrow{\hat{p}}$ & $\stackrel{m}{\uparrow}$ & & on \\
\hline & & $\cong$ & 1 & 1 & 1 & 1 & 1 & 1 & 1 & 1 & 1 & 1 & $\begin{array}{c}0 \\
\dot{p}\end{array}$ & $\overrightarrow{\hat{T}}$ & 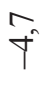 & ? \\
\hline & & 0 & 1 & 1 & 1 & 1 & 1 & 1 & 1 & 1 & 1 & 1 & $\stackrel{n}{+}$ & $\begin{array}{l}\infty \\
f^{0}\end{array}$ & $\stackrel{\circ}{+}$ & $\stackrel{\circ}{\rightarrow}$ \\
\hline \multirow{5}{*}{\multicolumn{2}{|c|}{ 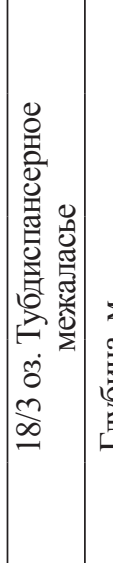 }} & 으 & 1 & 1 & 1 & 1 & 1 & 1 & 1 & 1 & 1 & 1 & $\stackrel{0}{i}$ & $\tilde{n}$ & $\stackrel{m}{i}$ & $\hat{0}$ \\
\hline & & in & 1 & 1 & 1 & 1 & 1 & 1 & 1 & 1 & 1 & I & $\stackrel{+}{i}$ & $\vec{i}$ & $\hat{i}$ & $\stackrel{+}{i}$ \\
\hline & & $m$ & 1 & 1 & 1 & 1 & 1 & 1 & 1 & 1 & 1 & 1 & $\underset{i}{\mathbf{i}}$ & $\begin{array}{l}0 \\
\dot{f}\end{array}$ & $\begin{array}{l}\infty \\
i\end{array}$ & $\stackrel{+}{+}$ \\
\hline & & $\cong$ & 1 & 1 & 1 & 1 & 1 & 1 & 1 & 1 & 1 & 1 & î & $\hat{i}$ & $\vec{p}$ & $\stackrel{+}{i}$ \\
\hline & & 0 & 1 & 1 & 1 & 1 & 1 & 1 & 1 & 1 & 1 & 1 & $\hat{i}$ & $\vec{q}$ & $\tilde{\tau}$ & $\mid \begin{array}{c}0 \\
\infty \\
\infty\end{array}$ \\
\hline \multirow{4}{*}{ 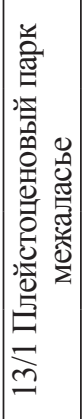 } & & \pm & हे & $\hat{i}$ & रे & $\tilde{n}^{n}$ & $\hat{i}$ & $\hat{\phi}$ & $\begin{array}{c}m \\
i^{n}\end{array}$ & $\stackrel{+}{\phi}$ & $\vec{n}$ & 崫 & $\hat{\tilde{y}}$ & $\begin{array}{l}0 \\
0\end{array}$ & $\begin{array}{l}\infty \\
\dot{+}\end{array}$ & $\stackrel{+}{\phi}$ \\
\hline & & 으 & के & $\begin{array}{l}\infty \\
0 \\
0\end{array}$ & $\hat{p}$ & $\hat{\varphi}$ & $\hat{n}$ & $\begin{array}{l}0 \\
0\end{array}$ & $\hat{\overrightarrow{+}}$ & $\hat{q}$ & $\mid \begin{array}{l}n \\
\forall\end{array}$ & $\hat{\theta}$ & $\begin{array}{l}\tilde{y} \\
\tilde{y}^{\prime}\end{array}$ & $\stackrel{0}{i}$ & $\begin{array}{l}0 \\
\nabla^{0}\end{array} \mid$ & : \\
\hline & & in & $\hat{i}$ & $\tilde{p}$ & $\begin{array}{l}+ \\
i p\end{array}$ & n & $\hat{n}^{2}$ & $\begin{array}{l}0 \\
i \\
i\end{array}$ & $\begin{array}{l}0 \\
\dot{t}^{+}\end{array} \mid$ & 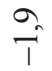 & $\hat{i}$ & $\hat{i}$ & $\stackrel{+}{+}$ & $\vec{\forall}$ & $\begin{array}{l}n \\
\tilde{t}^{2}\end{array}$ & गे \\
\hline & & $n$ & $\tilde{\hat{T}}$ & $\begin{array}{l}m \\
\tilde{n} \\
\tilde{n}\end{array}$ & $\hat{i}$ & $\hat{\hat{0}}$ & $\begin{array}{l}n \\
i \\
i\end{array}$ & $\stackrel{m}{\stackrel{2}{i}}$ & $\vec{T}$ & $\begin{array}{l}0 \\
\hat{\varphi}\end{array}$ & $\hat{\tilde{i}}$ & $\begin{array}{l}\infty \\
\stackrel{+}{*}\end{array}$ & $\begin{array}{c}0 \\
\stackrel{n}{1}\end{array}$ & $\overrightarrow{\hat{p}}$ & $\overrightarrow{\phi p}$ & $\stackrel{i}{i}$ \\
\hline \multirow{3}{*}{ 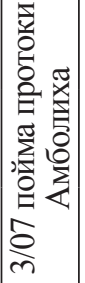 } & & $\vec{\sim}$ & $\hat{p}$ & $\vec{\varphi}$ & $\begin{array}{l}\infty \\
i p\end{array}$ & $\overrightarrow{0}$ & $\hat{i}$ & $\vec{\phi}$ & $\begin{array}{c}0 \\
i \\
i\end{array} \mid$ & $\overrightarrow{9}$ & $\begin{array}{l}n \\
p^{2}\end{array}$ & $\tilde{o}$ & $\begin{array}{l}n \\
i \\
1\end{array}$ & $\tilde{o}$ & $\begin{array}{l}n \\
i p\end{array}$ & $\vec{q}$ \\
\hline & & \pm & 8 & ?. & $\hat{\varphi}_{0}$ & $\stackrel{+}{\phi}$ & $\stackrel{\infty}{\infty}$ & $\hat{\imath}$ & $\begin{array}{c}0 \\
i \\
1\end{array} \mid$ & ?n & $\overrightarrow{\hat{p}}$ & $\stackrel{+}{\phi}$ & $\overrightarrow{\vec{t}^{2}}$ & $\begin{array}{l}n \\
\hat{q}\end{array}$ & 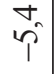 & $\stackrel{+}{\circ}$ \\
\hline & & $\nabla$ & $\overbrace{}^{m}$ & $\hat{i}$ & $\begin{array}{l}\sigma_{0} \\
\hat{n}\end{array}$ & $\bar{n}$ & $\vec{p}$ & $\tilde{F}$ & $\stackrel{+}{\hat{p}}$ & $\stackrel{\infty}{\uparrow}$ & $\hat{i}$ & $\hat{i}$ & î & $\begin{array}{l}\infty \\
i \\
i\end{array}$ & 0. & $\hat{0}$ \\
\hline \multicolumn{3}{|c|}{ 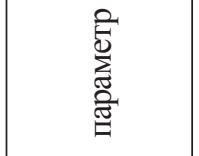 } & ठิ & $\ll$ & Ô & $\ll$ & 巳̂ & $\varangle$ & है। & $\varangle$ & 己े & $\varangle$ & है & $\ll$ & Oे & $\varangle$ \\
\hline \multicolumn{3}{|c|}{ 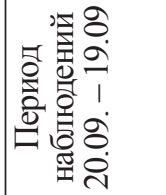 } & \multicolumn{2}{|c|}{ 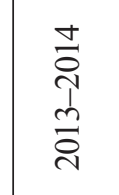 } & \multicolumn{2}{|c|}{ 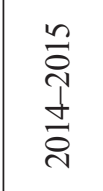 } & \multicolumn{2}{|c|}{ 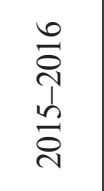 } & \multicolumn{2}{|c|}{ 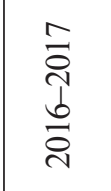 } & \multicolumn{2}{|c|}{$\frac{\infty}{\stackrel{\infty}{\grave{1}}}$} & \multicolumn{2}{|c|}{ 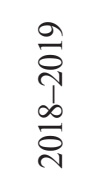 } & \multicolumn{2}{|c|}{$\begin{array}{l}\text { ठิ } \\
\text { } \\
\text { ळे } \\
\text { ते }\end{array}$} \\
\hline
\end{tabular}


Скважина 18/2 расположена на пологом склоне юго-восточной экспозиции. Среднегодовая температура грунтов на глубине 10 м в 2018-2019 гг. составила $-4,3^{\circ} \mathrm{C}$, а в 2019-2020 гг. $-4,4^{\circ} \mathrm{C}$, амплитуда температур составила $-1,7^{\circ} \mathrm{C}$ и $-1,4^{\circ} \mathrm{C}$ соответственно. На глубине 5 м среднегодовая температура составила в первый год наблюдений $-4,7^{\circ} \mathrm{C}$, во второй $-4,6^{\circ} \mathrm{C}$, на глубине $3 \mathrm{M}-5,1^{\circ} \mathrm{C}$ и $-4,7^{\circ} \mathrm{C}$, на глубине $1,2 \mathrm{M}$ $-5,6^{\circ} \mathrm{C}$ и $-4,7^{\circ} \mathrm{C}$.

В скв. 18/3 на межаласье с возрастом пожара 30 лет зафиксированы самые высокие показатели среднегодовой температуры грунтов на исследуемой территории. На глубине 10 м в 20182019 гг. температура составила $-2,0^{\circ} \mathrm{C}$, в 2019-2020 гг. $-2,3^{\circ} \mathrm{C}$, амплитуда $0,5^{\circ} \mathrm{C}$; на глубине 5 м $-2,4^{\circ} \mathrm{C}(2018-2019$ гг.) и $-2,7^{\circ} \mathrm{C}(2019-2020$ гг.), на глубине 3 м $-2,6^{\circ} \mathrm{C}$ и $-2,8^{\circ} \mathrm{C}$ соответственно, на глубине $1,2 \mathrm{M}-3,0^{\circ} \mathrm{C}$ и $-3,1^{\circ} \mathrm{C}$ соответственно.

На площадке 19/2 с пожаром 15-летней давности, расположенной на пойме р. Колы- мы, режимные наблюдения за температурой пород ведутся с 2019 г. Среднегодовая температура отложений на глубине 1 м в конце летнего сезона составляла $-1,0^{\circ} \mathrm{C}$ и в середине сентября начала снижаться до конца февраля, достигнув $-12,5^{\circ} \mathrm{C}$. Температура на глубине 9 м в течение года имела меньшую амплитуду и составила в среднем $-5,0^{\circ} \mathrm{C}$. Такие низкие температуры, вероятно, объясняются особенностью микрорельефа в виде кочкарника (высотой 0,5 м и более), в котором в начале лета все еще задерживается снежный покров, а после кочкарник затеняет поверхность, защищая от солнечной радиации.

На скв. 20/1 «г. Родинка» было выполнено однократное измерение температуры пород. Мощность слоя сезонного оттаивания на момент бурения составляла 0,8 м. Температура пород на глубине $3 \mathrm{M}-1,8^{\circ} \mathrm{C}$, на глубине $5 \mathrm{~m}-2,4^{\circ} \mathrm{C}$, на глубине $7 \mathrm{~m}-2,6^{\circ} \mathrm{C}$, и на забое $(9 \mathrm{M})$ зафиксирована температура $-2,5^{\circ} \mathrm{C}$. Мониторинговые работы на данной площадке будут продолжаться.

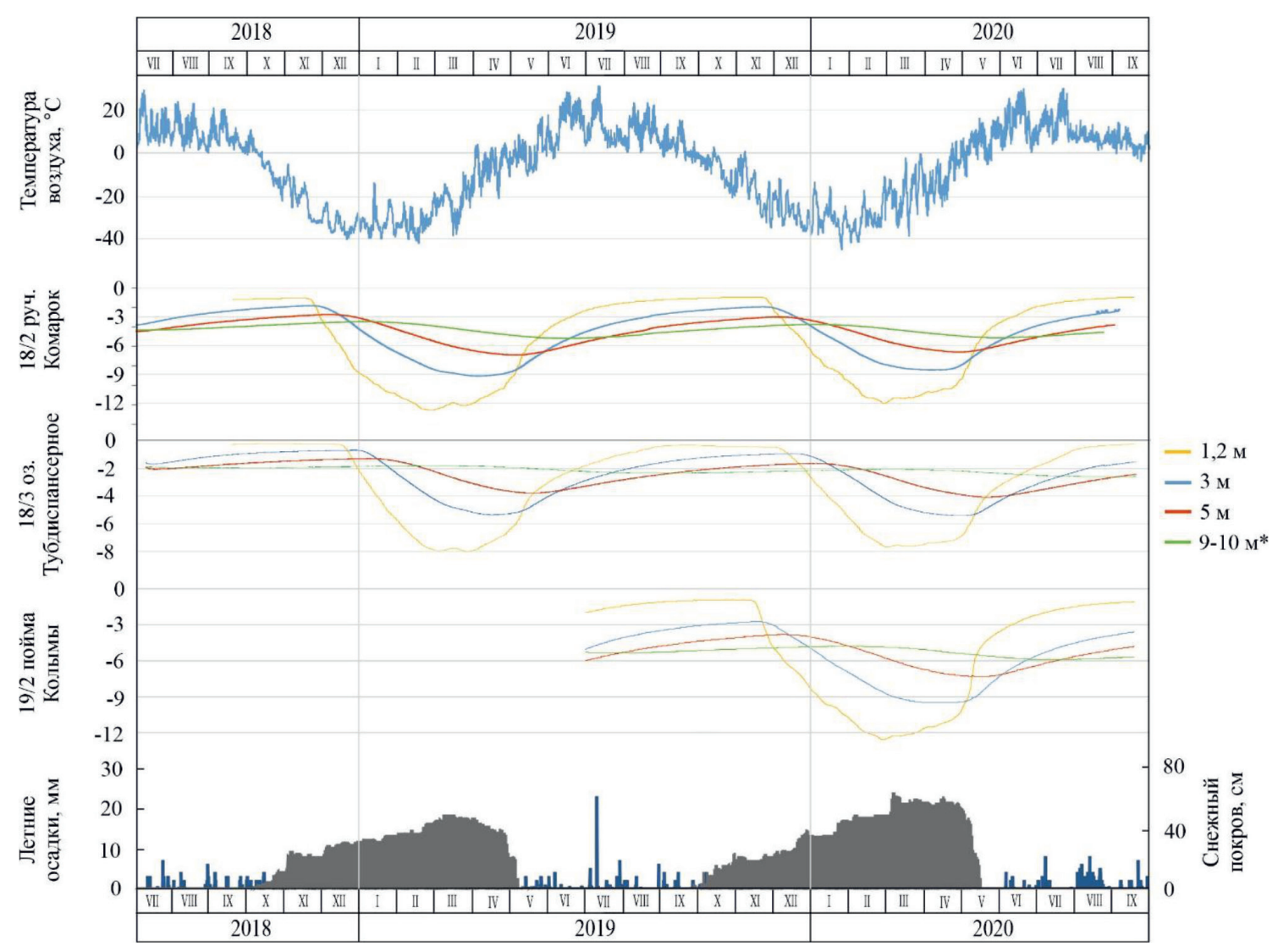

Рис. 6. Сопоставление метеоданных ст. Черский и температуры мерзльх пород по скважинам 18/2, $18 / 3$ и 19/2;

*_датчик на глубине 9 м для скв. 19/2, датчик на глубине 10 м для скв. 18/2 и 18/3 
Растительный покров играет существенную роль в процессе тепло-, влагообмена между поверхностью и атмосферой и в значительной степени определяет термический режим пород $[10,11]$. В случае лесного пожара в зависимости от типа огневой активности (почвенный, низовой переходящий в верховой) и его интенсивности изменяются тепловой и водный режимы грунтов. Также растительные сукцессии на постпирогенных участках будут развиваться по-разному. Известно, что в первые годы на постпирогенных участках повышается температура воздуха и почвы, увеличивается амплитуда их колебаний, нарушается влажностной режим почв и могут активизироваться негативные криогенные процессы. Вследствие этого на гарях создаются условия для интенсивного прогрева почв за счет поглощения солнечной радиации, ее затемненной от углей, золы и сажи поверхностью и сокращается затеняющая способность крон деревьев. Отмечается, что лесные пожары на рассматриваемых постпирогенных участках, подстилаемых ледовым комплексом, не инициировали процесс термокарста. В ходе работ на ключевых участках, несмотря на наличие современных морозобойных трещин на поверхности, термопросадок по полигональной сетке ледового комплекса обнаружено не было. Вероятно, некогда на местах пожарищ растительный покров относительно быстро восстанавливался, формируя более плотный лес, а короткий летний сезон сокращает время проникновения солнечной радиации.

\section{Заключение}

На основе выполненных работ установлено, что среднегодовая температура многолетнемерзлых пород на рассматриваемой территории севера Колымской низменности изменяется в широких пределах: от $-2,0^{\circ} \mathrm{C}$ на межаласье до $-6,0^{\circ} \mathrm{C}$ на пойме.

По результатам исследований выявлено, что самые низкие температуры пород подошвы слоя годовых теплооборотов в диапазоне от $-5,9^{\circ} \mathrm{C}$ до $-6,0^{\circ} \mathrm{C}$ зафиксированы на 2 участках: на пойме протоки Амболиха с ненарушенными условиями и на останце ледового комплекса высотой 6 м с возрастом пожара 120 лет. На склоне южной экспозиции, где пожар произошел 80 лет назад, температуры установились на отметке $-4,1^{\circ} \mathrm{C}$. Самые высокие значения температур отмечаются на участке с относительно недавним (30 лет назад) пожаром на межаласном типе местности: $-2,0^{\circ} \mathrm{C}$.
Результаты проведенных наблюдений за температурами грунтов показали, что процесс восстановления на нарушенных ключевых участках идет достаточно интенсивно, наблюдается стабилизация мерзлотных условий с каждой стадией сукцессионного развития растительности. Во время полевых работ на свежей гари (площадка 20/1) было отмечено, что восстановление растительного покрова начинается уже через 2 месяца после пожара в виде свежих травяных пучков в нижнем ярусе. Стабилизация температурного режима пород в некотором отношении зависит от степени зарастания гари. В ходе сукцессионного времени через 15-25 лет после пожара происходит стабилизация нарушенных условий.

Работа выполнена при поддержке гранma РФФИ № 18-05-00990 A.

\section{Список литературы / References}

1. Государственный доклад о состоянии окружающей природной среды РС(Я). Министерство экологии, природопользования и лесного хозяйства. [Электронный ресурс]. URL: https://minpriroda.sakha.gov.ru/gosdoklady-o-sostojaniiokruzhajuschej-sredy (дата обращения: 02.08.2021).

Governmental report on the state of environment Republic of Sakha (Yakutia). Ministerstvo ekologii, prirodopol'zovaniya i lesnogo khozyaystva. [Electronic resource]. URL: https://minpriroda.sakha.gov.ru/gosdoklady-o-sostojaniiokruzhajuschej-sredy (date of access: 02.08.2021) (in Russian).

2. Лыткина Л.П. Послепожарная динамика лесорастительных условий в лиственничных лесах Центральной Якутии // География и природные ресурсы. 2008. № 2. C. $181-185$.

Lytkina L.P. Post-fire dynamics of forest growth conditions in larch forests of central Yakutia// Geografiya i prirodnyye resursy. 2008. № 2. P. 181-185 (in Russian).

3. Чевычелов А.П. Лесные пожары в Якутии и их влияние на почвенный покров в аспекте прогнозируемого изменения климата // Вестник Северо-Восточного федерального университета им. М.К. Аммосова. Серия: Науки о Земле. 2019. № 1 (13). C. 55-67.

Chevychelov A. P. Forest fires in yakutia and their impact on soil cover in terms of predicted climate change // Vestnik Severo-Vostochnogo federal'nogo universiteta im. M.K. Ammosova. Seriya: Nauki o Zemle. 2019. № 1 (13). P. 55-67 (in Russian).

4. Alexander H.D., Natali S.M., Loranty M.M., Ludwig S., Spektor V.V., Davydov S.P., Zimov N.S., Mack M.C. Impacts of increased soil burn severity on larch forest regeneration on permafrost soils in far northeastern Siberia. Forest Ecology and Management. 2018. Vol. 417. P. 144-153. DOI: 10.1016/j. foreco.2018.03.008

5. Варламов С.П., Скрябин П.Н. Постпирогенная динамика гидротермического состояния грунтов криолитозоны Якутии // Успехи современного естествознания. 2016. № 5. C. $105-110$.

Varlamov S.P., Skryabin P.N. Post-fire changes in the hydrothermal state of permafrost in Yakutia // Uspekhi sovremennogo estestvoznaniya. 2016. № 5. Р. 105-110 (in Russian).

6. Скрябин П.Н., Варламов С.П. Термический режим грунтов нарушенных ландшафтов Центральной Якутии // Криосфера Земли. 2013. Т. 17. № 3. С. 44-49.

Skryabin P.N., Varlamov S.P. Ground thermal regime in disturbed landscapes of Central Yakutia // Kriosfera Zemli. 2013. Vol. 17. № 3. P. 44-49 (in Russian). 
7. Федоров А.Н., Мачимура Т., Герасимов Е.Ю., Петров М.И., Константинов П.Я., Ивахана Г., Кушида К., Такакай Ф., Десяткин А.Р., Сайто Х., Хаясака Х., Фукуда М. Влияние пожаров на мерзлотные ландшафты в Центральной Якутии // Наука и образование. 2008. № 4. С. 64-67.

Fedorov A.N., Machimura T., Gerasimov E.Yu., Petrov M.I., Konstantinov P.Ya., Iwahana G., Kushida K., Takakai F., Desyatkin A.R., Saito H., Hayasako H., Fukuda M. Vliyanie pozharov na merzlotnie landshafti v Centralnoi Yakutii Nauka i obrazovanie. 2008. № 4. P. 64-67 (in Russian).

8. ГОСТ 5180-2015. Грунты. Методы лабораторного определения физических характеристик. М.: Стандартинформ, 2019. $20 \mathrm{c}$.

9. ГОСТ 12536-79. Грунты. Методы лабораторного определения гранулометрического (зернового) и микроагрегатного состава. М.: Стандартинформ, 2019. 23 с.
10. Федоров-Давыдов Д.Г., Давыдов С.П., Давыдова А.И., Шмелев Д.Г., Остроумов В.Е., ХолодовА.Л., Сороковиков В.А. Термическое состояние почв Северной Якутии // Криосфера Земли. 2018. Т. XXII. № 3. С. 52-66.

Fedoryov-Davydov D.G., Davydov S.P., Davydova A.I., Shmelev D.G., Ostroymov V.E., Kholodov A.L., Sorokovikov V.A. The thermal state of soils in Northern Yakutia // Kriosfera Zemli. 2018. Vol. XXII. № 3. P. 52-66 (in Russian).

11. Федоров-Давыдов Д.Г., Давыдов С.П., Давыдова А.И., Остроумов В.Е., Холодов А.Л., Сороковиков В.А., Шмелев Д.Г. Температурный режим почв Северной Якутии // Криосфера Земли. 2018. Т. XXII. № 4. С. 15-24.

Fedoryov-Davydov D.G., Davydov S.P., Davydova A.I., Ostroymov V.E., Kholodov A.L., Sorokovikov V.A., Shmelev D.G. The temperature regime of soils in Northern Yakutia// Kriosfera Zemli. 2018. Vol. XXII. № 4. P. 15-24 (in Russian). 